\title{
Analysis of students' thinking level in solving Pythagoras' theorem problems based on Van hiele's theory
}

\author{
Sari Wulandari¹, Ali Syahbana1*, Tanzimah'1, Yilun Shang ${ }^{2}$, Robert Weinhandl ${ }^{3}$, \& Rajinder Sharma ${ }^{4}$ \\ ${ }^{1}$ Department of Mathematics Education, Universitas PGRI Palembang, Palembang, Indonesia \\ 2 Northumbria University, United of Kingdom \\ ${ }^{3}$ School of Education, STEM Education, Johannes Kepler University, Austria \\ ${ }^{4}$ University of Technology and Applied Sciences, Sohar, Oman \\ *Corresponding author: syahbanaumb@yahoo.com | Phone Number: +6281373340681
}

\section{ARTICLE INFO}

Received: 11-03-2021

Received in revised: 20-06-2021

Accepted: 17-08-2021

Available online: $30-10-2021$

\section{KEYWORDS}

Van Hiele's theory; Pythagorean Theorems;

Ability of Geometry;

Students' thinking level;

\section{A B S T R A C T}

The aims of this analysis are to explain the level of thinking of grade VIII students at SMP Negeri 1 Talang Ubi in solving Pythagorean Theorem questions based on Van Hiele's theory. The research approach used in this analysis is descriptive qualitative case study research. The subjects of this research were three students of grade VIII of SMP Negeri 1 Talang Ubi, South Sumatera Indonesia. The three students were chosen based on their test answers on the Pythagorean Theorem material, with one being a high-ability student, one being a medium-ability student, and one being a low-ability student. The study's data collection techniques included assessments, interviews, and documentation. Techniques for data processing include data reduction, data presentation, and conclusion. The findings revealed that high-ability students could complete all four stages of Van Hiele's thinking: imagination, interpretation, informal deduction, and deduction. Moderate students achieved three levels of Van Hiele's thinking, including visualization, analysis, and informal deduction, while low-ability students achieved only one level of Van Hiele's thinking, visualization.

\section{INTRODUCTION}

Education is one of the reasons that contribute to the advancement of the country and human life. Since education will produce talented people with bright ideas, ability, skills, and experience in preparation for a better future (Fitriyah et al., 2017). Humans who have received an education will see their lives progress in a positive way. Education cannot be distinguished from mathematics, which is a difficult subject in comparison to all other subjects. (Ulva \& Suri, 2019). According to Ferinaldi and Susanti (2018), mathematics is a topic that is taught at nearly all stages of education, and it is a fundamental knowledge that must be learned in order to promote student learning progress. As a result, pupils must be prepared for mathematics subjects beginning in primary school, well before kindergarten. Geometry is the most difficult subject for students to grasp in mathematics. Geometry, according to Abdussakir (2009), is a significant subject to study in mathematics. The many ideas found in geometry, as well as their use in real life, give geometry - a crucial place in the school mathematics curriculum. According to Musa et al. (2017), students' comprehension of geometric principles is poor and should be strengthened.

Several previous studies, such as (Usmadi, 2020; Samsuriadi \& Imron, 2019; Putriani \& Rahayu, 2018; Ridhollah et al, 2021; Sarah et al, 2021) found that learning models greatly affect students' ability to learn mathematics. This is in line with research (Paroqi et al, 2020; Yarmasi et al, 2020; Maulidawati et al, 2020; and Fonna \& Mursalin, 2019) that the learning process that occurs in the classroom is also strongly influenced by the model used by the teacher when conditioning students in learning mathematics. Along with the development of strategies, models, and methods of teaching teachers in learning theory where mathematics is one of the objects that receive the benefits of the new model. This is because mathematics is one of the subjects that need attention from research in the field of education. 
Other studies, for example (Baist et al., 2019; Mulyatna et al., 2021; A'yun et al., 2021) found that mathematics lessons not only foster critical thinking skills, but also provoke students' ability to be creative through solutions. mathematical problem. In line with (Erdogan, 2020; Rizki et al., 2018; Alex \& Mammen, 2012; Ma et al., 2015; Van Hiele, $1999)$ that another ability raised by mathematics lessons is geometric thinking which focuses students' concentration on understanding shapes. Basic geometric shapes, such as two-dimensional flat shapes, and three-dimensional shapes. It should be understood that mathematics is an important lesson to be taught to early childhood to facilitate abstraction knowledge during adolescence (Tieng \& Eu, 2014; Armah et al., 2018; Hamidah \& Kusuma, 2021; Oyebanji \& Idiong, 2021). According to Mersin et al., (2020) teacher awareness in teaching the ancient history of mathematics helps students to understand mathematics well, especially in constructing mathematics. Another way that teachers need to do to make it easier for students to solve mathematical problems is through a scaffolding approach (Lhechukwu, 2020). Moreover, trigonometry material requires contextual problems presented by the teacher (Rahmad, \& Qohar, 2020; Rahmatina \& Zaid, 2019; Puspitasari et al., 2019; Rahmah \& Munir, 2019; Subiyantari et al., 2019).

According to the National Council of Teaching of Mathematics (Mulyadi \& Muhtadi, 2019), the goals of studying geometry in high school are for students to be able to: (1) define, identify, and understand clearly the meanings and properties relevant to the forms of twodimensional shapes and three dimensions; understanding the association between angles, perimeter, volume, side length, and area of the same shape; and (3) developing and refuting deductive and inductive arguments regarding geometrical associations and concepts such as Pythagorean relations, comparisons, and congruence. Learning goals are needed so that learning exercises can proceed as planned.

The Pythagorean Theorem is a geometry concept learned in junior high school. It is a fundamental concept of mathematics. (Fitriyani \& Sugiman, 2014). As a result, students must understand the Pythagorean Theorem. According to Zaerani et al. (2017), as students grasp the Pythagorean principle, it becomes simpler for them to address questions about the Pythagorean Theorem, including questions about flat-sided forms.

Based on findings made at SMP Negeri 1 Talang Ubi, South Sumatera Indonesia, it was discovered that students were only taught concepts without regard for students' reasoning skills. As a result, students struggled to answer questions about the Pythagorean theorem. Students must be able to follow the stage of cognition and it will influence student learning outcomes. Analysis activities must be carried out to assess the skills that are under the students' level of cognition so that educators recognize the abilities exhibited by their students.

Van Hiele's theory of learning can be used in teaching and learning exercises to help students understand geometric principles, including the Pythagorean Theorem. According to Walle (2008), there are five stages of reasoning involved in learning and comprehending geometry: level 0 (visualization), level 1 (analysis), level 2 (informal deduction), level 3 (deduction), and level 4 (deduction) (rigor). Each level reflects the geometric thought process of the pupil. If you look at the level of thought of students' geometry that is founded on Van Hiele's theorem, the students' ability to interpret the lesson and mathematical communication abilities would be higher, and the object is not straightforward enough to be clear at the next level.

Utami et al (2016) performed a similar study, with the findings showing that as many as four students responded by meeting more than indicators for all levels, from level 0 to level 3, indicating that the student has van Hiele's level of thinking about level 3, namely deduction. This findings is in line with Razak et al (2017). Junior high school students are supposed to be able to achieve level 3 in geometric reasoning, according to Usiskin and Senk (Lestariyani et al, 2013). If children are unable to achieve level 3 thought geometry in junior high school, they would struggle to learn geometry in high school.

Each level of geometric thinking has distinct characteristics that distinguish students when it comes to recognizing and solving geometric problems. This disparity results in a variety of students' cognitive abilities and thinking levels, making it difficult for students to grasp the ideas that the teacher has learned. This article attempts to explain the level of thinking of high, medium, and lowability students in grade VIII SMP Negeri 1 Talang Ubi, South Sumatera Indonesia while solving Pythagorean Theorem questions based on Van Hiele's theory.

\section{METHOD}

This is a qualitative descriptive case study analysis that explains the thinking level of students with high, medium, and low abilities in resolving Pythagorean Theorem questions based on Van Hiele's theory. This study took place at SMP Negeri 1 Talang Ubi during the odd semester of the 2020/2021 academic year. The subjects of this study were 3 students from grade VIII.1 SMP Negeri 1 Talang Ubi, South Sumatera Idonesia. Each subject is represented the high, moderate, and low level of thingking. Test, interview, and documentations were conducted to find out the level of thinking of students' geometry based on Van Hiele's theory.

The student test results were then analyzed based on indicators from each level of Van Hiele's thinking which had been adjusted to the Pythagoras Theorem. The following is 
an indicator of Van Hiele's thinking level (modified from Musa, 2016) which is briefly described in Table 1.

Table 1. Van Hiele's Level of Thinking

\begin{tabular}{cl}
\hline Level & \multicolumn{1}{c}{ Indicators } \\
\hline $\begin{array}{c}\text { (visualization) } \\
\text { (analysis) }\end{array}$ & $\begin{array}{l}\text { Recognizing a triangle depending on the points it } \\
\text { measures. } \\
\text { Identify geometric form cases and non-examples. }\end{array}$ \\
\hline $\begin{array}{l}\text { Determining the length of the base side of a } \\
\text { triangle using the triangle's known properties. } \\
\text { Determining the length of the hypotenuse of a } \\
\text { triangle using the triangle's known properties. }\end{array}$ \\
\hline $\begin{array}{l}\text { (informal } \\
\text { deduction) }\end{array}$ & $\begin{array}{l}\text { Recognizing the relation between one form and } \\
\text { another. } \\
\text { Solving questions including the properties of } \\
\text { geometric shapes }\end{array}$ \\
\hline $\begin{array}{c}\text { (deduction) } \\
4\end{array}$ & $\begin{array}{l}\text { Understand axioms, definitions, theorems, and } \\
\text { proofs, as well as other mathematical claims. } \\
\text { Build proof deductively. }\end{array}$ \\
\hline $\begin{array}{l}\text { Recognize the existence of axioms as root } \\
\text { premises that can be used to prove the correctness } \\
\text { of a theorem. } \\
\text { Create a formal geometric proof of the theorem. }\end{array}$ \\
\hline
\end{tabular}

\section{RESULTS AND DISCUSSION}

The geometric thinking level test was administered to three students who were chosen as subjects. There are five questions on the geometric reasoning skill test. The outcomes of the experiments are shown in table 2. The following is an analysis based on the results of Van Hiele's geometric thinking skills test and interviews with the three subjects.

\section{Subject with high ability}

At the visualization stage, high-ability students correctly characterize triangles in the Cartesian plane in question $1 \mathrm{a}$, and students can decide the three points and discern which is the x-axis and which is the y-axis, so ST is asked to draw a triangle with all three points that are identified and reinforced by the interview results. Students use the formula for the gap between two points to prove the answer to number $1 \mathrm{~b}$, and the conclusions are right and ready to be proven in other ways. Then, in comparison to the other two students, students should name the features of a right triangle and draw it in depth. Students use this information to define a triangle diagram depending on the points they see. As a result, highly skilled students will progress to the visualization level.

Furthermore, the degree of interpretation is where high-ability students can accurately evaluate the length of a triangle's base side from an illustration and add detail to be understood and questioned. Students were able to identify and clarify what differentiated the two formulas in question number $2 \mathrm{a}$ based on the outcome of the interview.

However, students made errors in calculating the formula in question number $2 a$ and $2 b$, for example, the formula used in question number $2 \mathrm{a}$ was $B C^{2}=A C^{2}-A B^{2}$ students applied instead of subtracting Students with intermediate skills, on the other hand, respond correctly and though the formulas used are added together.

Students, on the other hand, may accurately correct their responses. Based on this, students can calculate the length of the base side of a triangle involving the triangle's recognized properties and the length of the hypotenuse of a triangle involving the triangle's recognized properties. This indicates that high-ability students have progressed to the level of analysis.

The level of informal deduction at which high-ability students can consider the association between one shape and another and incorporate facts to be learned and inquired about. Furthermore, even though they have trouble deciding what is being asked in the problem, students solve questions relating to the properties of geometric forms accurately and precisely. Students are asked to explain the steps in solving question number 3 . Students can explain each step appropriately. Based on this, students can understand the relationship between one shape and another and solve problems related to the properties of geometric shapes. In other words, high-ability students are already able to reach a level of informal deduction. Students are asked to clarify how they solved issue number three. Students should properly clarify each move. Based on this, students can consider the relationship between one shape and another and solve problems involving geometric shape properties. In other words, highability students will now engage in informal deduction.

At the level of deduction, the student will explain the condition in question and add details about Ahmad and Udin's positions to the Cartesian field triangle he developed. capable of demonstrating the portion that was previously requested in question 4 a Students struggle with painting, but when the interview is held, the students will accurately clarify each of Ahmad and Udin's positions. In the case of question $4 b$, the subject should correctly solve the problem and state the formula used to calculate the length of the hypotenuse. Students can understand many mathematical statements based on this, including axioms, definitions, theorems, and proofs. Create a proof by deduction.

Finally, the students' rigor level was insufficient to demonstrate whether Mr. Yadi's decision to purchase 900 trees was right. Students often use the solution incorrectly, and the steps in solving these problems are not understood by them. As the student is asked why he chose triangles $\mathrm{ABD}$ and $\mathrm{ABC}$, the answer must be separated by the angle of each triangle. The explanation for this is that students can not comprehend the context of the questions. This is what causes students to struggle with answering the questions. As a result, students are unable to comprehend the reality of axioms as root premises that can be used to prove the validity of a theorem and are unable to formally formulate 
proof of theorems in geometry. This means that high-ability students were unable to achieve the rigor level.

\section{Subject with moderate ability}

Students with moderate abilities can accurately identify triangles in the Cartesian plane in question number $1 \mathrm{a}$, and they can identify the three points and discern which are $\mathrm{x}$ and $y$ axes, so students are asked to draw a triangle with the three points that are identified and reinforced by the interview results. Students use the formula for the gap between two points to show the answer to number $1 \mathrm{~b}$, and the conclusion is correct, which can be seen in other ways. Students are asked to draw a triangle without a Cartesian plane as a result of answering question number $1 \mathrm{~b}$ correctly. Students use this information to define a triangle diagram depending on the points they see. As a result, that student progress the visualization level.

Furthermore, the level of analysis is defined as the ability of students with moderate abilities to correctly determine the length of the base side of a triangle from an image. Students, on the other hand, did not have material that was already identified and requested. Students were able to discern and clarify what differentiated the two formulas in questions $2 \mathrm{a}$ and $2 \mathrm{~b}$ based on the outcome of the interview. However if students write $B C^{2}=A C^{2}-A B^{2}$ in response to question number $2 \mathrm{a}$, the correct answer differs from that of high-ability students who answer incorrectly despite the fact that the formula used is added up. Students still have no trouble answering questions. Based on this, students can determine the length of the base side of a triangle involving the recognized properties of the triangle and determine the length of the hypotenuse of a triangle that involves the recognized properties of the triangle. This means that students with moderate abilities have reached the level of analysis. Based on this, students can calculate the length of the base side of a triangle involving the triangle's recognized properties and the length of the hypotenuse of a triangle involving the triangle's recognized properties. This indicates that students have progressed to the level of analysis.

Table 2. Van Hiele's Geometry Thinking Ability Test Results

\begin{tabular}{|c|c|c|c|c|c|c|c|}
\hline \multirow{3}{*}{ Students } & \multirow{3}{*}{ Category } & \multicolumn{5}{|c|}{ Level } & \multirow{3}{*}{ Level achievement } \\
\hline & & 0 & 1 & 2 & 3 & 4 & \\
\hline & & $1 a-1 b$ & $2 a-2 b$ & 3 & $4 a-4 b$ & 5 & \\
\hline ST & High & $\sqrt{ }$ & $\sqrt{ }$ & $\sqrt{ }$ & $\sqrt{ }$ & $\mathrm{X}$ & Level 3 \\
\hline SS & Moderate & $\sqrt{ }$ & $\sqrt{ }$ & $\sqrt{ }$ & $\mathrm{X}$ & $\mathrm{X}$ & Level 2 \\
\hline SR & Low & $\sqrt{ }$ & $\mathrm{X}$ & $\mathrm{X}$ & $\mathrm{X}$ & $\mathrm{X}$ & Level 0 \\
\hline
\end{tabular}

The level of student deduction will explain the condition in question and add detail on Ahmad and Udin's steps to the Cartesian field triangle he developed. Capable of demonstrating the portion that was previously requested in question 4a Students struggle with painting, but when the interview is held, the students will accurately clarify each of Ahmad and Udin's positions. In the case of question $4 \mathrm{~b}$, students can answer the problem correctly, but they are unable to call and apply the formula from the Pythagorean Theorem to find the length of the hypotenuse using that formula. As a result, students are unable to comprehend such mathematical concepts such as axioms, concepts, theorems, and proofs. Create a proof by deduction. This suggests that students with average abilities were unable to advance to the deduction level.

Finally, the students' rigor level was insufficient to demonstrate whether Mr. Yadi's decision to purchase 900 trees was right. Students still only know the formula for the area of a triangle, and the steps in solving the problem are not understood, and the proof's results are incorrect. Students were asked whether the outcome of calculating the BCD triangle was $24 \mathrm{~m}^{2}$. The explanation for this was that the students did not comprehend the significance of the questions. This is what causes students to struggle with answering the questions. As a result, students are unable to comprehend the reality of axioms as root premises that can be used to prove the validity of a theorem and are unable to formally formulate proof of theorems in geometry. This suggests that students with average skills were unable to meet the rigor standard.

\section{Subject with low ability}

Low-ability students can accurately define triangles in the Cartesian plane in question number $1 \mathrm{a}$, and students can determine the three points and discern which is the $\mathrm{x}$-axis and which is the y-axis, so students are asked to draw a triangle with all three points that are identified and reinforced by the interview results. Students use the formula for the gap between two points to prove their answer to number $1 \mathrm{~b}$, and the result is correct. Students, on the other hand, are unable to demonstrate this in any other way. Students could identify and draw the properties of a right triangle. However, the student answered the questions incorrectly because he did not name the other properties of a right triangle with an angle of $90^{\circ}$. The student then defines a triangle diagram depending on the points he sees. As a result, students with limited ability will progress to the visualization level.

Furthermore, low-ability students have not been able to accurately evaluate the length of the base side of a triangle 
from an illustration and do not add detail to be understood and questioned. According to the interview findings, students were unable to identify and clarify what differentiated the two formulas in questions $2 \mathrm{a}$ and $2 \mathrm{~b}$. The subject did not know the formula used during the interview. Students may see the difference between the triangle's three side lengths. Based on this, students are unable to decide the length of the base side of a triangle involving the known properties of the triangle, as well as the length of the hypotenuse of a triangle involving the recognized properties of the triangle. This means that lowability students have not been able to reach the level of analysis.

The level of informal deduction at which low-ability students are unable to grasp the association between one shape and another and fail to add details that is understood and requested. Furthermore, despite having trouble deciding what is being posed in the questions, the pupil is less able to solve problems relating to the properties of geometric forms accurately and specifically. In response to question 3 , the student should describe the steps he or she took to solve the problems, such as deciding the lengths of $\mathrm{AB}$ and $\mathrm{BD}$. When asking if the steps in solving the question is right, students fail to answer the third question in the interview, "Are you confident the steps you answered are correct?". This showed that students were unable to correctly answer the questions. As a result, students are unable to grasp the relationship between one shape and another and are unable to solve problems involving the properties of geometric forms. In other words, low-ability students have not reached the stage of informal deduction.

The level of student deduction is not able to describe the situation in question and has difficulty adding information to the steps of Ahmad and Udin's position to the triangle he made in the Cartesian field. Students can show the part that was asked in the previous $4 \mathrm{a}$ question. In the case of question $4 \mathrm{~b}$, students have not been able to solve the problem correctly and do not grasp the calculation used to calculate the duration of the hypotenuse. As a result, students are unable to grasp certain mathematical premises such as axioms, definitions, and theorems, as well as deduce proofs. This suggests that low-ability students were unable to progress to the deduction level.

Finally, the student was unable to demonstrate whether Mr. Yadi's decision to purchase 900 trees was right at the rigor stage. Students often misuse the formula and do not understand how to solve the problem. When asked whether the students determined the lengths of $A B$ and $B C$, the findings must include the fact that the students did not grasp the context of the questions. This is what causes students to struggle with answering the questions. As a result, students are unable to comprehend the reality of axioms as root premises that can be used to prove the validity of a theorem and are unable to formally formulate proof of theorems in geometry. This suggests that students with limited skills were unable to meet the rigor level.

\section{CONCLUSION}

In terms of students' level of thinking in answering Pythagorean Theorem problems based on Van Hiele's theory, the following can be concluded: 1). The Student with exceptional abilities was shown to be capable of reaching the four levels of the Van Hiele theory. It was shown that students could answer questions containing measures of the level of visualization, level of analysis, level of informal deduction, and level of deduction. Students should accurately and correctly justify their responses to the questions asked during the interview. 2). The Student with moderate abilities turned out to be able to reach 3 stages of the Van Hiele Theory. It is shown that students can solve questions that contain indicators of the level of visualization, the level of analysis, and the level of informal deduction. She clarify her responses during the interview. Students, on the other hand, struggle to learn the levels of deduction and rigor. Students may justify their responses to the questions posed during the interview process, but they are often reluctant to explain the questions asked. 3). Students with low abilities turned out to be able to reach 1 stage of the Van Hiele Theory. It was shown that the students were only able to solve one of the five questions that contained indicators at the Van Hiele level. Students are only able to achieve at the visualization level. Students have difficulty mastering the level of informal deduction, level of deduction, and level of rigor. In the interview process, students cannot explain the answers to the questions posed correctly, are still slow in answering, and are confused because they do not master the Pythagorean theorem material.

\section{REFERENCES}

Abdussakir. (2009). Pembelajaran Geometri Sesuai Teori Van Hiele. Madrasah:Jurnal Pendidikan dan Pembelajaran Dasar, 2(1). D0I: https://doi.org/10.18860/jt.v2i1.1832

Alex, J. K., \& Mammen, K. J. (2012). A survey of South African grade 10 learners' geometric thinking levels in terms of the Van Hiele theory. The Anthropologist, 14(2), 123-129.

Armah, R. B., Cofie, P. O., \& Okpoti, C. A. (2018). Investigating the Effect of van Hiele Phase-Based Instruction on Pre-Service Teachers' Geometric Thinking. International journal of Research in Education and Science, 4(1), 314-330.

A'yun, Q., Yanuarti, R., \& Sujiwo, D. A. C. (2021). Performance Analysis of Students Through Critical Thinking Ability Based on Mathematic Ability. Malikussaleh Journal of Mathematics Learning (MJML), 4(1), 23-27. DOI: https://doi.org/10.29103/mjml.v4i1.2737

Baist, A., Fadillah, A., \& Nopitasari, D. (2019). Students SelfRegulated Learning in Numerical Methods Course using Computational Mathematics Teaching Materials. 
Malikussaleh Journal of Mathematics Learning (MJML), 2(1), 1-4. DOI: https://doi.org/10.29103/mjml.v2i1.2122

Erdogan, F. (2020). Prospective Middle School Mathematics Teachers' Problem Posing Abilities in Context of Van Hiele Levels of Geometric Thinking. International Online Journal of Educational Sciences, 12(2).

Ferinaldi, \& Susanti, A. (2018). Pengaruh Model Pembelajaran Coop Co-op terhadap Pemahaman Konsep Ditinjau Dari Gaya Belajar Visual, Audio, Kinestetik Siswa Kelas VIII SMPN 43 Merangin. Jurnal Edumatica, 8(1 ), 23-35.

DOI: https://doi.org/10.22437/edumatica.v8i01.4115

Fitriyah, Murtadlo, A., \& Warti, R. (2017). Pengaruh Model Pembelajaran Discovery Learning Terhadap Hasil Belajar Matematika Siswa MAN Model Kota Jambi. Jurnal Pelangi, 9 (2 ), 108-112. DOI: https://doi.org/10.22202/jp.2017.v9i2.1898

Fitriyani, W., \& Sugiman. (2014). Pengembangan Perangkat Pembelajaran Teorema Pythagoras Dengan Pendekatan IDEAL Berbantuan Geogebra. Jurnal Riset Pendidikan Matematika, 1(2), 268-284. DOI: https://doi.org/10.21831/jrpm.v1i2.2681

Fonna, M., \& Mursalin, M. (2019). Using of wingeom software in geometry learning to improving the of mathematical representation ability. Malikussaleh Journal of Mathematics Learning (MJML), 1(2), 40-43. DOI: https://doi.org/10.29103/mjml.v1i2.1174

Hamidah, H., \& Kusuma, J. W. (2021). The Improving Students' Mathematics Results and Interest Through Online-Based Flipped Classroom Models. Malikussaleh Journal of Mathematics Learning (MJML), 4(1), 7-12. DOI: https://doi.org/10.29103/mjml.v4i1.2919

Lestariyani, S., Ratu, N., \& Yunianta, T. N. (2013). Identifikasi Tahap Berpikir Geometri Siswa SMP Negeri 2 Ambarawa Berdasarkan Teori Van Hiele. Jurnal Penelitian Pengembangan Kependidikan, 30(2), 96-103. DOI: https://doi.org/10.24246/j.sw.2014.v30.i2.p96-103

Lhechukwu, N. B. (2020). Impact of Instructional Scaffolding Approach on Secondary School Students Achievement in Mathematics. Malikussaleh Journal of Mathematics Learning, 3(2), 46-50. https://eric.ed.gov/?id=EJ1283339

Ma, H. L., Lee, D. C., Lin, S. H., \& Wu, D. B. (2015). A Study of Van Hiele of Geometric Thinking among 1st through 6th Graders. Eurasia Journal of Mathematics, Science and Technology Education, 11(5), 1181-1196.

Maulidawati, M., Muhammad, I., Rohantizani, R., \& Mursalin, M. (2020). The Implementation of Make a Match Type Cooperative Learning Model to Improve the Mathematical Connection Ability. International Journal for Educational and Vocational Studies, 2(11). DOI: https://doi.org/10.29103/ijevs.v2i11.3319

Mersin, N., Karabörk, M. A., \& Durmuş, S. (2020). Awareness of preservice mathematics teachers about prehistoric and ancient number systems. Malikussaleh Journal of Mathematics Learning (MJML), 3(2), 57-61. DOI: https://doi.org/10.29103/mjml.v3i2.2904
Mulyadi, I., \& Muhtadi, D. (2019). Proses Berpikir Siswa dalam Menyelesaikan Masalah Geometri Berdasarkan Teori Van Hiele. JP3M:Jurnal Penelitian Pendidikan dan Pengajaran Matematika, 5(1), 1-8. DOI: https://doi.org/10.37058/jp3m.v5i1.661

Mulyatna, F., Imswatama, A., \& Rahmawati, N. D. (2021). Design Ethnic-Math HOTS: Mathematics Higher Order Thinking Skill Questions Based On Culture and Local Wisdom. Malikussaleh Journal of Mathematics Learning (MJML), 4(1), 48-51. DOI: https://doi.org/10.29103/mjml.v4i1.3059

Musa, L. A. (2016). Level Berpikir Geometri Menurut Teori Van Hiele Berdasarkan Kemampuan Geometri dan Perbedaan Gender Siswa Kelas VII SMPN 8 Pare-Pare. $a L$ Khwarizmi:Jurnal Pendidikan Matematika dan Ilmu Pengetahuan Alam, 4(2), 103-116. DOI: https://doi.org/10.24256/jpmipa.v4i2.255

Musa, M. R., Ikhsan, M., \& Zaura, B. (2017). Peningkatan Kemampuan Berpikir Kritis melalui Penerapan Model Pembelajaran Berbasis Teori Van Hiele di Kelas IX SMP Negeri Banda Aceh. Jurnal Ilmiah Mahasiswa Pendidikan Matematika Vol. 2 (2), 9-17.

http://www.jim.unsyiah.ac.id/pendidikanmatematika/article/view/10048

Oyebanji, M. S., \& Idiong, U. S. (2021). Challenges of Teaching Mathematics to Students with Visual Impairment. Malikussaleh Journal of Mathematics Learning (MJML), 4(1), 1-6. DOI: https://doi.org/10.29103/mjml.v4i1.2538

Paroqi, L. L., Mursalin, M., \& Marhami, M. (2020). The Implementation of Realistic Mathematics Education Approach to Improve Students' Mathematical Communication Ability in Statistics Course. International Journal for Educational and Vocational Studies, 2(10). DOI: https://doi.org/10.29103/ijevs.v2i10.3311

Putriani, D., \& Rahayu, C. (2018). The effect of discovery learning model using sunflowers in circles on mathematics learning outcomes. International Journal of Trends in Mathematics Education Research, 1(1), 22-25. DOI: https://doi.org/10.33122/ijtmer.v1i1.26

Puspitasari, E., Masitoh, S., \& Jannah, M. (2019). Testing the Effect of Smart Egg Puzzle Games on Understanding the Geometry Concepts of Early Childhood. International Journal for Educational and Vocational Studies, 1(1), 68-71. DOI: https://doi.org/10.29103/ijevs.v1i1.1490

Razak, F., Sutrisno, A. B., \& Immawan, A. Z. (2017). Analisis Tingkat Berpikir Siswa Berdasarkan Teori Van Hiele Ditinjau Dari Gaya Kognitif. Prosiding Seminar Nasional, 3 (1), 75-83.

DOI: https://doi.org/10.22437/edumatica.v7i02.4214

Rahmad, F. M., \& Qohar, A. (2020). Improving Proof Ability of Prospective Teachers with a Contextual Model on Trigonometry. Malikussaleh Journal of Mathematics Learning (MJML), 3(1), 4-7. DOI: https://doi.org/10.29103/mjml.v3i1.2339 
Rahmah, N. A. L., \& Munir, A. (2019). Rationale as an Innovative Learning Application to Improve Students' Critical Thinking in Argumentative Writing. International Journal for Educational and Vocational Studies, 1(7), 744-749. DOI: https://doi.org/10.29103/ijevs.v1i7.1745

Rahmatina, D., \& Zaid, N. M. (2019). Perceptions of teachers, principals and school supervisors on students' skills using ICT in learning in the Senior High School. Malikussaleh Journal of Mathematics Learning (MJML), 2(1), 19-22. DOI: https://doi.org/10.29103/mjml.v2i1.610

Ridhollah, M., Muliana, M., \& Mursalin, M. (2021). The Influence of Cooperative Integrated Reading and Composition Model on Completing Abilities of Story Questions. Malikussaleh Social and Political Reviews, 2(1), 33-42. DOI: https://doi.org/10.29103/mspr.v2i1.4978

Rizki, H. T. N., Frentika, D., \& Wijaya, A. (2018, March). Exploring students' adaptive reasoning skills and van Hiele levels of geometric thinking: a case study in geometry. In Journal of Physics: Conference Series (Vol. 983, No. 1, p. 012148). IOP Publishing.

Sarah, K., Mursalin, M., Muliana, M., Nuraina, N., \& Rohantizani, R. (2021). The Influence of the Inside Outside Circle Cooperative Learning Model on Students' Mathematical Communication Ability. International Journal for Educational and Vocational Studies, 3(3), 177-185. DOI: https://doi.org/10.29103/ijevs.v3i3.4981

Samsuriadi, S., \& Imron, M. A. (2019). The Effect of Think Pair Share (TPS) Learning Model with Problem Solving Approach on the Student's Math Communication in MA DA Jarowaru. Malikussaleh Journal of Mathematics Learning (MJML), 2(1), 9-12. DOI: https://doi.org/10.29103/mjml.v2i1.2125

Subiyantari, A. R., Muslim, S., \& Rahmadyanti, E. (2019). Effectiveness of Jigsaw cooperative learning models in lessons of the basics of building construction on students learning'outcomes viewed from critical thinking skills. International Journal for Educational and Vocational Studies, 1(7), 691-696. DOI: https://doi.org/10.29103/ijevs.v1i7.1653
Tieng, P. G., \& Eu, L. K. (2014). Improving Students' Van Hiele Level of Geometric Thinking Using Geometer's Sketchpad. Malaysian online journal of educational technology, 2(3), 20-31.

Ulva, M., \& Suri, I. R. (2019). Pengaruh Model Pembelajaran Auditory Intellectualy Repetition Terhadap Kemampuan Komunikasi Matematis Peserta Didik. UNION: Jurnal Pendidikan Matematika Vol.7 (1), 15-21. https://core.ac.uk/download/pdf/230371783.pdf

Usmadi, U., Hasanah, H., \& Ergusni, E. (2020). The impact of the implementation three-step Interview cooperative learning model in mathematics learning toward the learners' activities and outcomes. Malikussaleh Journal of Mathematics Learning (MJML), 3(1), 8-12. DOI: https://doi.org/10.29103/mjml.v3i1.2447

Utami, M. W., Setiawan, T. B., \& Oktavianingtyas, E. (2016). Tingkat Berpikir Geometri Siswa Kelas VII-B SMP Negeri 1 Jember Materi Segiempat Berdasarkan Teori Van Hiele Ditinjau Dari Hasil Belajar Matematika. Jurnal Edukasi UNEJ Vol. 3 (2), 43-47. DOI: https://doi.org/10.19184/jukasi.v3i2.3529

Van Hiele, P. M. (1999). Developing geometric thinking through activities that begin with play. Teaching children mathematics, 5(6), 310-316.

Walle, J. A. (2008). Sekolah Dasar dan Menengah Matematika Pengembangan Pengajaran Jilid 2. Jakarta: Erlangga.

Yarmasi, Y., Fonna, M., \& Mursalin, M. (2020). The Influence of Cooperative Learning Model Type Team Assisted Individualized of Interactive Media Assistance to Students' Mathematical Communication Ability. International Journal for Educational and Vocational Studies, 2(9). DOI: https://doi.org/10.29103/ijevs.v2i9.3303

Zaerani, S., Mardhiah, \& Suharti. (2017). Pengaruh Penguasaan Konsep Teorema Pythagoras Terhadap Kemampuan Menyelesaikan Soal-Soal Bangun Ruang Sisi Datar pada Siswa Kelas VIII MTs Negeri Balang-Balang. MaPan:Jurnal Matematika dan Pembelajaran Vol. 5 (2), 279-292. http://repositori.uin-alauddin.ac.id/7153/ 